\title{
CENNÝ PRÍSPEVOK K FRAZEOLOGICKÝM VÝSKUMOM
}

(Jasna Uhláriková. Somatická frazeológia v slovenčine a srbčine. Nový Sad:

Filozofická fakulta, 2021, 173 s.)

Mnohí súčasní frazeológovia vo svojich výskumoch upozorňujú na nedostatočnú preskúmanost' frazeológie, aj ked’ je prítomná a prirodzená v každom jazyku. Jej rýchla expanzia v posledných rokoch otvára priestor pre stále nové témy a nastol'uje d’alšie otázky, na ktoré hl'adala odpovede aj Dr. Jasna Uhláriková, docentka a vedúca Oddelenia slovakistiky Filozofickej fakulty Univerzity v Novom Sade. Knižné vydanie jej frazeologických výskumov, ktorého vydavatel’om je Filozofická fakulta Univerzity v Novom Sade, uzrelo svetlo sveta v polovici roka 2021 ako monografila s názvom Somatická frazeológia v slovenčine a srbčine. Sem zaradené príspevky sú individuálnym výstupom projektu Diskurzy menšinových jazykov, literatúr a kultúr $v$ juhovýchodnej a strednej Európe (číslo projektu: 178017), ktorý financuje Ministerstvo osvety, vedy a technologického rozvoja Republiky Srbsko.

Doc. Dr. Uhláriková na začiatku čitatel’ov uvádza do skúmanej problematiky a vysvetl'uje štruktúru monografie. Predmetom jej výskumu bola slovenská a srbská somatická frazeológia, t. j. frazémy, ktoré v štruktúre obsahujú lexému pomenúvajúcu čast' l'udského tela. Autorkiným ciel’om bolo zhromaždit' a utvorit' fond s maximálnym počtom slovenských a srbských somatických frazém a podrobit' ich kvantitatívnej, štruktúrno-komponentovej a sémantickej analýze uplatnením niekol'kých vedeckých metód. Opierala sa pritom o výskumy popredných slovenských a srbských frazeológov. Výskumnú vzorku tvorilo viac ako 3500 spisovných celonárodných frazém, ktoré boli vyexcerpované z výkladových a frazeologických slovníkov.

Príspevky v monografii sú rozvrhnuté do dvoch častí. Prvú čast', ktorá obsahuje devät' kapitol, tvoria výsledky výskumov realizované počas autorkiných doktorandských štúdií, resp. ide o upravenú dizertačnú prácu, ktorá bola v roku 2016 obhájená na Filozofickej fakulte Univerzity v Novom Sade. Desiata kapitola v druhej časti knihy obsahuje príspevky prezentované na domácich a zahraničných vedeckých konferenciách uverejnené v domácich a medzinárodných publikáciách. Monografiu uzatvára poznámkový aparát, menný register, jazykové pramene, použitá literatúra a autorkin životopis. 
V prvej kapitole Vývin frazeológie sa docentka Uhláriková zaoberá otázkami, ktoré súvisia so vznikom a rozvojom tejto disciplíny. Ako konštatuje, intenzívny záujem o frazeológiu sa prejavil až v posledných dvoch desat'ročiach. Ked’ ide o vojvodinskú slovakistiku, jej prvoradým záujmom neboli frazeologické témy, ale skúmanie interferenčných javov na všetkých úrovniach, ktoré vznikli pod vplyvom srbského jazyka na slovenský. Napriek tomu už v sedemdesiatych rokoch minulého storočia vzniklo niekol'ko frazeologických štúdií, ktorých autormi sú slovenskí vojvodinskí lingvisti. V poslednom desat'ročí narastá počet vedeckých príspevkov v oblasti frazeológie, takže dnes už možno hovorit' o kontinuitnom záujme o frazeologické otázky vo vojvodinskej slovakistike. V tom kontexte $\mathrm{v}$ osobitných podkapitolách doc. Dr. Uhláriková podáva prehl'ad vývinu slovenskej a srbskej frazeológie $\mathrm{v}$ európskom kontexte, prehl'ad komparatívnych a konfrontačných výskumov slovenskej a srbskej frazeológie, informácie o začiatkoch a vývine vojvodinskej slovakistiky, prehlaad frazeologických príspevkov vojvodinskej slovakistiky v období 1976 až 2005, prehl’ad súčasných frazeologických výskumov vojvodinskej slovakistiky (frazeologické výskumy po roku 2005), ako i chronologický prehl'ad kontrastívnych vedeckých príspevkov o slovenskej a srbskej frazeológii. Autorka si všíma aj pozoruhodné výsledky srbskej frazeológie, ktorá ma pomerne neskoré začiatky. Srbské slovníky napr. zachytávajú väčší počet frazém než slovenské a v srbčine existuje aj niekol'ko jednojazyčných frazeologických slovníkov, čo slovenskej frazeológii ešte stále chýba.

Druhá kapitola Vymedzenie frazeológie prináša predovšetkým teoretické otázky súvisiace so skúmanou problematikou. V rámci nej sa $\mathrm{v}$ osobitných podkapitolách píše aj o problémoch s vyčlenením frazeológie ako osobitnej jazykovednej (pod)disciplíny, resp. o rôznych názoroch v chápaní jej osobitostí a teoreticko-metodologických vymedzení. Autorka sa zamýšla aj nad otázkou, prečo používame frazémy a uzatvára to slovami, že "frazeológia ako alternatíva reči je prizmou človeka vo vzt’ahu k svetu, ktorý ho obklopuje”. Teoretické otázky sú aj obsahom tretej kapitoly $O$ základnej jednotke frazeológie. Ćítame tu o vlastnostiach frazémy, o slovách ako komponentoch frazém, o otázke určenia rozsahu a hraníc frazém a ich variantných a invariantných podobách. Opísané sú tu aj pokusy o všeobecnú definíciu frazémy, o vymedzenie základnej jednotky frazeológie frazémy a i. Na základe teoretických zistení slovenských a srbských lingvistov autorka dospieva k záveru, že neexistuje všeobecné kritérium, ktoré sa dá aplikovat' na frazeológiu vcelku. Skúmanú problematiku charakterizuje rôznorodost' frazém a konfigurácií ich vlastností. Názory slovenských a srbských lingvistov na danú problematiku sú však jednotné a chápanie frazeológie v skúmaných jazykoch je 
ustálené. Štvrtá kapitola je venovaná somatickým lexémam vo frazeológii (Somatické lexémy vo frazeológii).

V pokračovaní monografie autorka začína vysvetl'ovat' postup práce a výskumu. V piatej kapitole Výber výskumnej vzorky a pramene uvádza zoznam somatických lexém, ktoré sú v štruktúre analyzovaných frazém. Šiesta kapitola sa zaoberá zapisovaním frazém (Zapisovanie frazém). Vzhl’adom na existujúcu nejednotnost' doc. Dr. Uhláriková navrhuje jeden zo spôsobov, ako uvádzat' variantné, fakultatívne a premenlivé slová vo frazémach. V siedmej kapitole Kvantitatívny rozsah frazém vysvetl'uje proces a etapy excerpovania a spracovania získanej výskumnej vzorky a podáva výsledky kvantitatívnej analýzy, ktoré ukazujú, že frazeologický obraz sveta v slovenskom a srbskom jazyku na základe frazém, ktoré vo svojom komponentovom zložení obsahujú somatickú lexému, sa zhoduje takmer na $50 \%$.

V ôsmej kapitole Formálna stránka slovenských a srbských somatických frazém autorka píše o štruktúrno-kompozičnej analýze slovenskej a srbskej somatickej frazeológie, funkčnej zat’aženosti somatických lexém vo frazémach, o výskyte dvoch alebo viacerých somatických lexém v rámci jednej frazémy, o výskyte konštrukčných typov $\mathrm{v}$ slovenskej a srbskej somatickej frazeológii a v tomto rámci detailnejšie o somatických frazeotextémach, somatických frazeolexémach a minimálnych frazémach.

Deviata kapitola Významová stránka slovenskej a srbskej somatickej frazeológie sa zaoberá problematikou sémantickej frazeologickej motivácie založenej na metafore, metonymii, synekdoche, prirovnaní, perifráze a antitéze. V pokračovaní autorka venuje pozornost’ významovej stránke slovenských a srbských frazém motivovaných somatizmami. Predmetom osobitných podkapitol sú sémantické mikroskupiny v somatickej frazeológii s lexémou oko, tvár, zub a srdce.

Druhá čast' knihy, desiata kapitola pod názvom Konceptualizácia emócií v somatickej frazeológii, sa zaoberá výskumom zastúpenia a vyjadrovania emócií v slovenskej somatickej frazeológii a je v nej uplatnený kognitívny prístup. Predmetom autorkinho záujmu bola konceptualizácia primárnych emócií so zameraním na emócie radost', strach, hnev, smútok, odpor/hnus, prekvapenie a tiež konceptualizácia lásky v slovenskej somatickej frazeológii.

V závere je podané zhrnutie získaných poznatkov, ako teoretických, tak aj výsledkov praktického výskumu.

Svojím obsahom a spôsobom podania predmetu a výsledkov výskumu monografia Somatická frazeológia $v$ slovenčine a srbčine doc. Dr. Jasny Uhlárikovej osloví tak odborného čitatel'a, ako aj všetkých záujemcov o 
frazeologickú problematiku. Obsahuje cenné a užitočné informácie, akými sú nielen výsledky výskumu slovenskej a srbskej somatickej frazeológie, ale i zhrnutie teoretických východísk a poznatkov o frazeológii oboch skúmaných jazykov, ktoré sú $\mathrm{v}$ knihe podané prehl'adne, jasným a zrozumitel'ným vedeckým štýlom. Opierajúc sa o popredných frazeológov a ich základné odborné práce v tejto oblasti, ako aj o novšie výskumy s iným prístupom $\mathrm{k}$ frazeologickému výskumu, vytvorila autorka pre súčasných a budúcich bádatel'ov slovenskej a srbskej frazeológie svojráznu stručnú frazeologickú učebnicu. Sledujúc pritom bibliografické odkazy, čitatel' získava prehl'ad o slovenskej a srbskej relevantnej literatúre súvisiacej so skúmanou problematikou. Kapitoly, v ktorých sa pozornost' venuje prehl'adom komparatívnych a konfrontačných výskumov slovenskej a srbskej frazeológie a prehl'adom frazeologických príspevkov vo vojvodinskej slovakistike, opodstatnene možno chápat' ako dejiny slovenskej vojvodinskej frazeológie, ktoré pre záujemcov o skúmanú problematiku predstavujú východisko $\mathrm{v}$ ich budúcich výskumoch a vzácnu informáciu o vývine a stave tejto jazykovednej (pod)disciplíny u nás.

Dr. Anna Margaréta Lačoková Univerzita v Novom Sade Filozofická fakulta Oddelenie slovakistiky anna.margareta.lacok@ff.uns.ac.rs DOI: 10.19090/gff.2021.2.251-254 